RASĀYAN J. Chem.

Vol. 14 | No. 2 |871-876| April - June | 2021

ISSN: 0974-1496 | e-ISSN: 0976-0083 | CODEN: RJCABP

http://www.rasayanjournal.com

http://www.rasayanjournal.co.in

\title{
AMYLASE, PROTEASE, AND LIPASE ACTIVITY OF BUTTERFLY OF Junonia almana AND Junonia atlites
}

\author{
N. M. Saptarini ${ }^{\varpi}$, D. Rahayu, and N. Yesita \\ Department of Pharmaceutical Analysis and Medicinal Chemistry, Faculty of Pharmacy, \\ Universitas Padjadjaran, 45363, Jatinangor, Indonesia \\ ${ }^{\square}$ Corresponding Author: nyi.mekar@unpad.ac.id
}

\begin{abstract}
Major gut digestive enzymes of butterflies are hydrolytic enzymes, i.e. amylase, protease, and lipase. Junonia is the most abundant butterfly species in the arboretum area of Universitas Padjadjaran, West Java, Indonesia. This study was aimed to determine the amylase, protease, and lipase activity of butterflies of Junonia almana and Junonia atlites. All enzyme activity was measured at the maximum wavelength of remaining substrates or products with the UVvisible spectrophotometric method. Both butterflies have higher amylase activity than protease and lipase activity. Amylase activity of $J$. atlites higher than J. almana at its optimum temperature and $\mathrm{pH}$, i.e. $37^{\circ} \mathrm{C}$ and 6.8 . This study has provided the first information about amylase, protease, and lipase activity in J. atlites and J. almana butterfly.
\end{abstract}

Keywords: Arboretum, Butterfly, Hydrolytic Enzyme, Indonesia

RASĀYAN J. Chem., Vol. 14, No.2, 2021

\section{INTRODUCTION}

Enzymes have specificity in the catalyzed reaction and substrates. Enzyme activity is influenced by substrate concentration, temperature, and $\mathrm{pH}$. Amylase, lipase, and protease enzymes are hydrolytic enzymes, which degraded macromolecules. ${ }^{1,2}$ Enzymes, as biocatalysts for biological reactions, help butterflies to digest their food. The butterfly life cycle is relatively short (2-6 months) and breeds rapidly. ${ }^{3}$ Butterflies are the highest number in the insect order, around 2500 species exist in Indonesia. There are 600 butterfly species in Java and Bali islands, Indonesia., ${ }^{4,5}$ This condition allows the availability of butterflies for enzyme production on a large scale. ${ }^{6}$

The genus of Junonia (Nymphalidae) is an important system model for experimental research in Lepidoptera. This system of development and evolution of this genus can be applied to all other genera. The most abundant genus of Junonia in the arboretum area of Universitas Padjadjaran, West Java, Indonesia, is Junonia almana (peacock pansies) and Junonia atlites (gray pansies) ${ }^{7,8} \mathrm{~J}$. almana is distributed in an Asian tropical area. ${ }^{9}$ These species consume Acanthaceae, Amaranthaceae, Apocynaceae, Asteraceae, Fabaceae, and Verbenaceae. ${ }^{710,11} \mathrm{~J}$. atlites has similar behavior to other Junonia, except when spawning. ${ }^{12}$ The major gut digestive enzymes of these two butterflies, the hydrolytic enzymes, have never been studied. In this study, we report the amylase, protease, and lipase activity in J. atlites and J. almana.

\section{EXPERIMENTAL}

\section{Experimental animal}

Junonia almana and Junonia atlites butterflies were collected from December 2014 to February 2015 from the arboretum area of Universitas Padjadjaran, West Java, Indonesia. Butterflies were identified by the Laboratory of Animal Taxonomy, Department of Biology, Universitas Padjadjaran. The procedures and protocols of the enzyme activity assay were reviewed and approved by the Health Research Ethics Committee, Faculty of Medicine, Universitas Padjadjaran No. 732/UN6.C2.1.2/KEPK/PN/2014.

\section{Chemical Materials}

All analytical grade of chemicals were purchased from Merck, Germany, i.e. acetonitrile, Coomasie brilliant blue (CBBG), ethanol, hydrochloric acid, iodine, phosphoric acid, potassium iodide, sodium chloride, sodium hydrogen phosphate, sodium hydroxide, sodium phosphate, and soluble starch. Bovine 
RASĀYAN $J$. Chem.

Vol. 14 | No. 2 |871-876| April - June | 2021

serum albumin (BSA), $p$-nitrophenol ( $p$-NP), $p$-nitrophenyl palmitate ( $p$-NPP), and tyrosine were purchased from Sigma-Aldrich, USA.

\section{Protein Extraction}

The butterfly wings were cut carefully. The bodies were weighed, then extracted with $0.02 \mathrm{M}$ sodium phosphate buffer ( $\mathrm{pH} 6.8$ ) containing $10 \mathrm{mM} \mathrm{NaCl}$ at $4{ }^{\circ} \mathrm{C}$ for $2 \mathrm{~h}$. Each extract was centrifuged at $4{ }^{\circ} \mathrm{C}$ and $13,000 \mathrm{G}$ for $30 \mathrm{~min}$. The supernatants were collected and stored at $-20^{\circ} \mathrm{C} .{ }^{13}$

\section{Determination of Total Protein Content}

Five concentrations of BSA, extracts, and blank were prepared. The Bradford reagent was added to each solution. The absorbance was measured at $573 \mathrm{~nm}$ after 5 min incubation. ${ }^{14}$

\section{Amylase Activity Assay}

The starch solution $(3 \mathrm{~mL})$ and each butterfly extract $(250 \mu \mathrm{L})$ were incubated for $8 \mathrm{~min}$. Hydrochloric acid $(0.5 \mathrm{~mL})$ and iodine $(0.5 \mathrm{~mL})$ were added, the absorbance was measured at $627 \mathrm{~nm} .{ }^{15}$ Amylase activity was calculated by Eqn.-1.

$$
\mathrm{U} / \mathrm{mg}=\frac{\text { Astd-Asampl }}{\text { Astd }} \times \frac{(\mathrm{mg}) \text { Starch }}{(\mathrm{mL}) \text { Enzyme in Extract } \times \text { Total Volume } \times \text { Time }}
$$

\section{Protease Activity Assay}

The casein solution $(1 \mathrm{~mL})$ and each butterfly extract $(250 \mu \mathrm{L})$ were incubated for $30 \mathrm{~min}$. Ethanol $(1 \mathrm{~mL})$ was added, placed in a boiling water bath for $5 \mathrm{~min}$, then cooled to the ambient temperature. Each mixture was centrifuged for $10 \mathrm{~min}$ at $13,000 \mathrm{G}$ and the absorbance was measured at $277 \mathrm{~nm} .{ }^{16}$ Protease activity was calculated by Eqn.-2.

$$
\mathrm{U} / \mathrm{mg}=\frac{\mu \mathrm{mol} \text { Tirosin which produce }}{\mathrm{mg} \text { Enzyme in Extract } \mathrm{x} \text { Time }}
$$

\section{Lipase Activity Assay}

The substrate solution $(1 \mathrm{~mL})$ and each butterfly extract $(250 \mu \mathrm{L})$ were incubated for $15 \mathrm{~min}$. The substrate solution was phosphate buffer: ethanol: $p$-NPP solution $(95: 4: 1)$. Ethanol $(1 \mathrm{~mL})$ was added and the absorbance was measured at $405 \mathrm{~nm} .{ }^{17}$ Lipase activity was calculated by Eqn.-3.

$$
\mathrm{U} / \mathrm{mg}=\frac{\mu \mathrm{mol} \text { pNP which produce }}{\text { mg Enzyme in Extract } \mathrm{x} \text { Time }}
$$

\section{Statistical analysis}

Data were showed as mean and standard deviation (SD), then analyzed by single-factor ANOVA, followed by Duncan Multiple Range Test (DMRT). Data were considered to be significantly different if $p$-value < $0.05 . .^{18}$

\section{Protein Extraction}

\section{RESULTS AND DISCUSSION}

The butterflies of J. almana and J. atlites were collected from December 2014 to February 2015, due to the highest rainfall in arboretum area, which increases butterfly populations associated with the plant fertility level as the butterfly host plant. ${ }^{19}$ The rainfall level affected the nectar availability. High water availability causes an increase in plants releasing nectar through the flowers. ${ }^{20}$ This study collected $72 \mathrm{~J}$. almana butterflies $(8.67 \mathrm{~g})$ and $53 \mathrm{~J}$. atlites butterflies $(5.22 \mathrm{~g})$. Butterfly's body produces a crude extract with a concentration was $14.29 \mathrm{mg} / \mathrm{mL}$ for J. almana and $14.28 \mathrm{mg} / \mathrm{mL}$ for J. atlites. All crude extract was stored at $-20^{\circ} \mathrm{C}$, to stop all enzymatic reactions that cause protein degradation or produce adverse substances. ${ }^{21}$

\section{Determination of Total Protein Content}

Bradford's method ${ }^{14}$ with BSA as a standard was used to determine the total protein content. In the Bradford method, the amount of protein-CBBG complex is proportional to the positive charge on the protein. ${ }^{22}$ The 
RASĀYAN J. Chem.

Vol. 14 | No. 2 |871-876| April - June | 2021

maximum wavelength of the protein-CBBG complex was $573 \mathrm{~nm}$, which corresponds to its complementary or transmitted color, i.e. orange wavelength $(570-620 \mathrm{~nm}){ }^{23}$

The correlation coefficient of the BSA calibration curve was 0.995 , which met the ICH criteria. ${ }^{24}$ It showed that instrument response is equal to the concentration. The absorbance of crude extract of $J$. atlites and $J$. almana was $0.78 \pm 0.01$ and $0.85 \pm 0.01$, respectively. The calculated total protein content of $J$. atlites and $J$. almana with a linear regression equation was $83.30 \pm 0.10$ and $90.21 \pm 0.09 \mu \mathrm{g} / \mathrm{mL}$, respectively. The total protein content of $J$. atlites was lower than J. almana, which significantly different $\left(p=1.76 \times 10^{-7}\right)$. These values were higher than the total protein content of Catopsilia pomona butterfly $(71.98 \pm 0.18$ $\mu \mathrm{g} / \mathrm{mL}) .{ }^{13}$ Crude extract of $J$. almana and J. atlites contain $58.30 \%$ and $60.63 \%$ of protein, respectively. This result showed that the crude extracts contain non-protein compounds which soluble in phosphate buffer.

In this study, the optimum $\mathrm{pH}$ and temperature of amylase, protease and lipase were determined. At optimum $\mathrm{pH}$, the enzyme three-dimensional structure is the most convenient to binding to the substrate. When the hydrogen ion concentration change, the enzyme activity is progressively lost until the enzyme became denatured. ${ }^{25} \mathrm{pH}$ alteration occurs in amino acid residues to maintain the tertiary and the quaternary structure of the active enzyme. ${ }^{26}$ Increased temperature causes increased kinetic energy, thereby increased the collision intensity between the substrate and the enzyme. Further increased temperature will decrease enzyme activity, due to denaturation. Enzymes encounter conformational changes at high temperatures, causes the substrate inhibition to enter the active site of the enzyme. ${ }^{25}$

\section{Amylase Activity Assay}

The sensitivity of amylase activity which determines with iodimetry by the Fuwa method (mg of starch equivalents consumed/min) was five times higher than the activity units (mg of glucose equivalents produced/min) measured with the dinitrosalysilic acid method. ${ }^{27}$ The starch type with the glucose number difference affects the formed starch-iodine complex. ${ }^{15}$

Butterflies need monosaccharides as an energy source of nectar. When a butterfly flies, the needed energy increase, so there will be increased amylase activity. The butterflies are dependent on the amylase endurance, ${ }^{28}$ cause when fly, the butterfly's temperature is more than $30{ }^{\circ} \mathrm{C}$ or $5-10{ }^{\circ} \mathrm{C}$ higher than normal body temperature. In insects, most amylase is active at neutral or slightly acidic $\mathrm{pH} .{ }^{29,30}$

Table-1: Amylase Activity in Various Temperature and $\mathrm{pH}$

\begin{tabular}{|c|c|c|c|c|}
\hline \multirow{2}{*}{\multicolumn{2}{|c|}{ Parameter }} & \multicolumn{2}{|c|}{ Amylase activity (U/mg) } & \multirow{3}{*}{$\begin{array}{c}p \text {-value } \\
5.46 \times 10^{-5}\end{array}$} \\
\hline & & J. atlites & J. almana & \\
\hline \multirow{3}{*}{$\begin{array}{c}\text { Temperature } \\
\left({ }^{\circ} \mathrm{C}\right)\end{array}$} & 27 & $6.41 \pm 0.01$ & $6.28 \pm 0.01$ & \\
\hline & 37 & $8.08 \pm 0.01$ & $7.61 \pm 0.01$ & $8.36 \times 10^{-7}$ \\
\hline & 47 & $6.60 \pm 0.06$ & $6.82 \pm 0.01$ & $4.42 \times 10^{-5}$ \\
\hline \multirow{3}{*}{$\mathrm{pH}$} & 5.8 & $3.16 \pm 0.01$ & $2.93 \pm 0.01$ & $4.42 \times 10^{-5}$ \\
\hline & 6.8 & $6.41 \pm 0.01$ & $6.28 \pm 0.01$ & $5.46 \times 10^{-5}$ \\
\hline & 7.8 & $1.98 \pm 0.02$ & $0.78 \pm 0.01$ & $3.64 \times 10^{-8}$ \\
\hline
\end{tabular}

The optimum temperature and $\mathrm{pH}$ of $J$. atlites and $J$. almana amylase were $37{ }^{\circ} \mathrm{C}$ and 6.8. Amylase activity of $J$. atlites was better than $J$. almana at optimum temperature and $\mathrm{pH}$. The amylase activity of both butterflies was significantly different (Table-1). The optimum temperature and $\mathrm{pH}$ of $J$. atlites and $J$. almana were similar to the stomach amylase of hemiptera insects, i.e. $25-40{ }^{\circ} \mathrm{C}^{31}$ and $6.5,{ }^{32}$ respectively. The butterflies are active at $16-42{ }^{\circ} \mathrm{C}$ and $28-30{ }^{\circ} \mathrm{C}$ is requiring for flight. ${ }^{19}$ The decreased amylase activity at $47^{\circ} \mathrm{C}$ caused by exposure of the hydrophobic residues to the enzyme surface which important to stabilize the amylase structure. Amylase activity at $47^{\circ} \mathrm{C}$ was higher than $27^{\circ} \mathrm{C}$, which indicates amylase has a high resistance to extreme environments. The charge of amino acid residues at the optimum $\mathrm{pH}$ is in an appropriate state, so the enzyme activity is efficient. ${ }^{33}$

The amylase activity of $J$. atlites and $J$. almana was higher than $C$. pomona butterfly at $27^{\circ} \mathrm{C}$, i.e. $5.85 \pm$ $0.01 \mathrm{U} / \mathrm{mg}$, but lower than C. pomona butterfly, at 37 and $47^{\circ} \mathrm{C}$, i.e. $8.21 \pm 0.01$ and $7.74 \pm 0.11 \mathrm{U} / \mathrm{mg}$, 


\section{RASĀYAN J. Chem.}

Vol. 14 | No. 2 |871-876| April - June | 2021

respectively..$^{13}$ These results showed that amylase of C. pomona more stable than $J$. atlites and $J$. almana in different temperatures. The amylase activity of $J$. atlites and J. almana was higher than C. pomona butterfly at the studied $\mathrm{pH}$. These results showed that amylase of $J$. atlites and J. almana more active than C. pomona in different $\mathrm{pH}$.

\section{Protease Activity Assay}

Insects need protein for structural proteins, enzymes, receptors, transporters, and storage. ${ }^{34}$ The protease activity was determined based on the amount of producing tyrosine from casein hydrolysis, then measured at $277 \mathrm{~nm}$, i.e. the maximum wavelength of the aromatic amino acids. ${ }^{35}$

Table-2: Protease Activity in Various Temperature and $\mathrm{pH}$

\begin{tabular}{|c|c|c|c|c|}
\hline \multirow{2}{*}{\multicolumn{2}{|c|}{ Parameter }} & \multicolumn{2}{|c|}{ Protease activity (U/mg) } & \multirow{2}{*}{$p$-value } \\
\hline & & J. atlites & J. almana & \\
\hline \multirow{3}{*}{$\begin{array}{l}\text { Temperature } \\
\left({ }^{\circ} \mathrm{C}\right)\end{array}$} & 27 & $0.76 \pm 0.02$ & $1.27 \pm 0.01$ & $1.42 \times 10^{-6}$ \\
\hline & 37 & $0.29 \pm 0.01$ & $1.11 \pm 0.01$ & $5.34 \times 10^{-7}$ \\
\hline & 47 & $0.20 \pm 0.01$ & $0.45 \pm 0.01$ & $7.88 \times 10^{-8}$ \\
\hline \multirow{3}{*}{$\mathrm{pH}$} & 5.8 & $0.39 \pm 0.01$ & $0.64 \pm 0.01$ & $4.62 \times 10^{-5}$ \\
\hline & 6.8 & $0.76 \pm 0.02$ & $1.27 \pm 0.01$ & $1.42 \times 10^{-6}$ \\
\hline & 7.8 & $0.43 \pm 0.01$ & $0.65 \pm 0.01$ & $4.45 \times 10^{-8}$ \\
\hline
\end{tabular}

The optimum temperature and $\mathrm{pH}$ of $J$. atlites and J. almana protease were $27^{\circ} \mathrm{C}$ and 6.8 . Protease activity of $J$. almana was better than $J$. atlites at optimum temperature and $\mathrm{pH}$. The amylase activity of both butterflies was significantly different (Table-2). The optimum temperature of J. atlites and J. almana were similar to the stomach protease of Ectomyelois ceratoniae, i.e. $30^{\circ} \mathrm{C}$ with casein as the substrate. ${ }^{36} \mathrm{The}$ optimum $\mathrm{pH}$ of $J$. atlites and $J$. almana were classified as neutral protease, correspond to the general body $\mathrm{pH}$ of the insect ${ }^{37}$ and in the range of protease, i.e. 7.0 to 9.0, due to serine protease in the extract. ${ }^{38}$ Both protease activities decreased with increasing temperature. This result showed that amylase work more dominant than protease, when a butterfly flies, due to nectar degradation as an energy source.

At the optimum temperature and $\mathrm{pH}$, protease activity of both butterflies was higher than C. pomona, i.e. $0.59 \pm 0.01 \mathrm{U} / \mathrm{mg} .{ }^{13}$ These results showed that protease of $J$. atlites and J. almana more active than $C$. pomona in studied temperature and $\mathrm{pH}$.

\section{Lipase Activity Assay}

Lipase activity was determined based on hydrolysis ester bonds in the oil as the substrate into glycerol and its fatty acids. ${ }^{39}$

Table-3: Lipase Activity in Various Temperature and $\mathrm{pH}$

\begin{tabular}{|c|c|c|c|c|}
\hline \multirow{2}{*}{\multicolumn{2}{|c|}{ Parameter }} & \multicolumn{2}{|c|}{ Lipase activity (U/mg) } & \multirow{3}{*}{$\frac{p \text {-value }}{1.12 \times 10^{-12}}$} \\
\hline & & \multirow{2}{*}{$\frac{\text { J. atlites }}{2.46 \pm 0.06 \times 10^{-4}}$} & \multirow{2}{*}{$\begin{array}{c}\text { J. almana } \\
21.43 \pm 0.02 \times 10^{-4}\end{array}$} & \\
\hline \multirow{3}{*}{$\begin{array}{c}\text { Temperature } \\
\left({ }^{\circ} \mathrm{C}\right)\end{array}$} & 27 & & & \\
\hline & 37 & $1.79 \pm 0.04 \times 10^{-4}$ & $4.38 \pm 0.03 \times 10^{-4}$ & $1.11 \times 10^{-8}$ \\
\hline & 47 & $2.15 \pm 0.03 \times 10^{-4}$ & $5.68 \pm 0.02 \times 10^{-4}$ & $1.85 \times 10^{-8}$ \\
\hline \multirow{3}{*}{$\mathrm{pH}$} & 5.8 & $3.75 \pm 0.04 \times 10^{-4}$ & $5.88 \pm 0.02 \times 10^{-4}$ & $1.14 \times 10^{-5}$ \\
\hline & 6.8 & $2.46 \pm 0.06 \times 10^{-4}$ & $21.43 \pm 0.02 \times 10^{-4}$ & $1.12 \times 10^{-12}$ \\
\hline & 7.8 & $1.22 \pm 0.02 \times 10^{-4}$ & $9.71 \pm 0.02 \times 10^{-4}$ & $2.05 \times 10^{-11}$ \\
\hline
\end{tabular}

The optimum temperature of $J$. atlites and $J$. almana lipase activity was $27^{\circ} \mathrm{C}$, while pH optimum was 5.8 for $J$. atlites and 6.8 for $J$. almana. Lipase activity of J. almana was higher than J. atlites at optimum temperature and $\mathrm{pH}$. The lipase activity of both butterflies was significantly different (Table-3). The optimum temperature of $J$. atlites and J. almana were similar to lipase activity in Ectomyelois ceratoniae, i.e. $30^{\circ} \mathrm{C} .{ }^{36}$ The optimum $\mathrm{pH}$ of $J$. atlites and J. almana were in the range of lipase activity in insects, i.e. 5.5-7.5. ${ }^{40,41}$ Both lipase activities decreased with increasing temperature. When flying, the dominant enzyme was amylase, due to energy production from nectar degradation. At the optimum temperature and $\mathrm{pH}$, lipase activity of both butterflies was higher than C. pomona, i.e. $0.59 \pm 0.01 \mathrm{U} / \mathrm{mg} .{ }^{13}$ These results showed that lipase of J. atlites and J. almana more active than C. pomona in studied temperature and $\mathrm{pH}$. 
RASĀYAN J. Chem.

Vol. 14 | No. 2 |871-876| April - June | 2021

\section{CONCLUSION}

Junonia atlites and Junonia almana have higher amylase activity than protease and lipase activity at optimum temperature and $\mathrm{pH}$.

\section{REFERENCES}

1. F.J. Okoko, O. Ogbomo, Continental Journal of Microbiology, 4, 1(2010).

2. J. Yu, Insect Biochemistry, 19(1), 103(1989), DOI:10.1016/0020-1790(89)90015-2

3. C.A. Triplehrn, N.F. Johnson, Borror and DeLong's Introduction to the Study of Insects, $7^{\text {th }}$ ed, Thomson Brook/Cole, California (2005).

4. K. Kunte, Butterflies of Peninsular India, Indian Academy of Sciences, India (2006).

5. H. Soekardi, A. Larasati, A. Djausal, Martinus, Lampung butterflies, Sahabat Alam Foundation, Bandar Lampung, Indonesia (2016).

6. M. Amir, W.A. Noerdjito, S. Kahono, Butterflies of the Mount Halimun National Park West Java, BCP-JICA LIPI Cibinong, Bogor, Indonesia (2003).

7. D. Vane-Wright, W. J. Tennent, Systematics and Biodiversity, 9(4), 289(2011), DOI:10.1080/14772000.2011.640497

8. J.M. Marcus, Evolution and Development, 7(2), 108(2005), DOI:10.1111/j.1525-142X.2005.05012.X

9. U. Kodandaramaiah, A. Vallin, C. Wiklund, Animal Behaviour, 77(6), 1415(2009), DOI:10.1016/j.anbehav.2009.02.018

10. S. Igarashi, H. Fukuda, The Life Histories of Asian Butterflies, Vol. I, Tokai University Press, Tokyo (1997).

11. B.M. Rayalu, E. Rao, S. Deepika, J.B. Atluri, IOSR Journal of Enviromental Science, Toxicology and Food Technology, 1(2), 17(2012), DOI:10.9790/2402-0121721

12. A.V.L. Freitas, D. Murray, K.S. Brown Jr., Journal of Lepidopterists' Society, 56(3), 117(2002)

13. N.M. Saptarini, D. Rahayu, F. Seviana, International Journal of ChemTech Research, 11(2), 311(2018), DOI:10.20902/IJCTR.2018.110237

14. M. Bradford, Analitycal Biochemistry, 72(1-2), 248 (1976), DOI:10.1016/0003-2697(76)90527-3

15. H. Fuwa, The Journal of Biochemistry, 41(5), 583(1954), DOI:10.1093/oxfordjournals.jbchem.a126476

16. V.A. Tamhane, N.P. Chougule, A.P. Giri, A.R. Dixit, M.N. Sainani, V.S. Gupta, Biochimica et Biophysica Acta (BBA): General Subjects, 1722(2), 156 (2005), DOI:10.1016/j.bbagen.2004.12.017

17. U.K. Winkler, M. Stuckmann, Journal of Bacteriology, 138(3), 663(1979), DOI:0021-9193/79/06$0663 /$

18. H.M. Kotkar, P.J. Sarate, V.A. Tamhane, V.S. Gupta, A.P. Giri, Journal of Insect Physiology, 55(8), 663(2009), DOI: 10.1016/j.jinsphys.2009.05.004

19. H. Davies, C.A. Butler, Do butterflies bite?: Fascinating answers to questions about butterflies and moths, Rutgers Univ Press, New Jersey (2008).

20. H. Harmonis, Rimba Kalimantan Fakultas Kehutanan Unmul, 13(2), 99(2008).

21. P.J. Sarate, V.A. Tamhane, H.M. Kotkar, N. Ratnakaran, N. Susan, V.S. Gupta, A.P. Giri, Journal of Insect Science, 12(42), 1(2012), DOI:10.1673\%2F031.012.4201

22. J. Markwell, Assay for Determination of Protein Concentration, in: Current Protocols in Protein Science, John Wiley \& Sons, New York (2007).

23. G.D. Christian, P.K. Dasgupta, K.A. Schug, Analytical Chemistry, $7^{\text {th }}$ ed, John Wiley \& Sons, New York (2014).

24. http://www.fda.gov/downloads/drugs/guidancecomplianceregulatoryinformation/guidances/ucm0733 84.pdf

25. D. Nelson, M. Cox, Lehninger Principles of Biochemistry, $4^{\text {th }}$ ed, W.H. Freeman and Company, New York (2005).

26. T. Palmer, P.L. Bonner, Enzymes: Biochemistry, Biotechnology, Clinical Chemistry, Woodhead Publisher, Cambridge, UK (2007).

27. Z. Xiao, R. Storms, A. Tsang, Analytical Biochemistry, 351(1), 146(2006), DOI:10.1016/j.ab.2006.01.036 
RASĀYAN J. Chem.

Vol. 14 | No. 2 |871-876| April - June | 2021

28. M. Mehrabadi, A.R. Bandani, F. Saadati, M. Mahmudvand, Journal of Agricultural Science and Technology, 13 (Suppl.), 1173(2011)

29. J.E. Baker, Insect Biochemistry, 13(4), 421(1983), DOI:10.1016/0020-1790(83)90026-4

30. W.R. Terra, T. Cristofoletti, Comparative Biochemistry and Physiology Part B: Biochemistry and Molecular Biology, 113(4), 725(1996), DOI:10.1016/0305-0491(95)02037-3

31. A.R. Bandani, M. Kazzazi, M. Mehrabadi, Entomological Science, 12(1), 25(2009), DOI:10.1111/j.1479-8298.2009.00303.x

32. F. Zeng, C. Cohen, Archives of Insect Biochemistry and Physiology, 44(3), 136(2000), DOI:10.1002/1520-6327(200007)44:3\%3C136::AID-ARCH5\%3E3.0.CO;2-2

33. P.B. Pelegrini, A.M. Murad, F.M. Grossi-De-Sá, L.V. Mello, L.A.S. Romeiro, E.F. Noronha, R.A. Caldas, O.L. Franco, Archives of Insect Biochemistry and Physiology, 61, 77(2006), DOI:10.1002/arch.20099

34. R.F. Chapman, The insects: Structure and function, $4^{\text {th }}$ ed, Cambridge University Press, Australia (1998).

35. A. Tokarzewicz, E. Gorodkiewicz, Chemik, 69(2), 81(2015).

36. M. Ranjbar, A. Zibaee, J.J. Sendi, Frontiers in Life Science, 8(1), 64(2015), DOI: $10.1080 / 21553769.2014 .961616$

37. M.J. North, Microbiology Reviews, 46(3), 308(1982).

38. M. Ajamhassani, Z. Arash, J.S. Jalal, A. Hassan, F. Nasser, Journal of Plant Protection Research, 52(3), 1(2012), DOI:10.2478/v10045-012-0061-0

39. L.E. Canavoso, S. Frede, E.R. Rubiolo, Insect Biochemistry and Molecular Biology, 34(8), 845(2004), DOI:10.1016/j.ibmb.2004.05.008

40. L.A.M. Grillo, D. Majerowicz, K.C. Gondim, Insect Biochemistry and Molecular Biology, 37(6), 579(2007), DOI:10.1016/j.ibmb.2007.03.002

41. Y. Hirayama, H. Chino, Insect Biochemistry, 17(1), 85(1987), DOI:10.1016/0020-1790(87)90147-8

[RJC-6175/2020] 